\title{
The Internationalization of Public Policy and the Prospects for a Theory of Multi-Level Governance \\ Ian Roberge
}

\section{$\underline{\text { Introduction }}^{\text {ii }}$}

Globalization represents a significant paradigm shift in political science. Whereas well into the 1990s, most sub-fields of the discipline focused on the nation-state, the actions of governments, and the relationships between governments and other societal actors, globalization has forced us to revise many of our existing theories. In a truly globalizing environment, politics cannot focus solely on the state. Scholars across the discipline have moved away from studying governments to studying governance within both a national and international context. Domestically, the evolving interest in the policy network/community approach demonstrates the increasing role of the private and community sectors in governance arrangements. Internationally, regime theory has extended the frontiers of political science to study private regimes, multinational corporations and the ever-increasing importance of NGOs. Despite calls from scholars like Rosenau to speak of a post-international system following the end of the Cold war ${ }^{1}$, or from Keohane and Milner to better understand the relationship between domestic politics and international politics ${ }^{2}$, little theorizing work has actually been able to incorporate knowledge from the sub-fields of political science in order to present a truly holistic view of the emerging global order.

An essential component of globalization is that it is driving the internationalization of

\footnotetext{
i Ian Roberge is a Ph.D. candidate at McMaster University.

${ }^{i i}$ This paper is based on interviews that I conducted in the Canadian banking industry in the fall of 2002 . Therefore, I would like to acknowledge the support of interviewees in this research project.

Ian Roberge, "The Internationalization of Public Policy and the Prospects for a Theory of Multi-Level Governance." Federal Governance: A Graduate Journal of Theory and Politics. 1:2 (2003)

$<$ http://cnfs.queensu.ca/federalgovernance/index.html>
} 
public policy. By this, I mean that few policy issues are strictly of a national nature any longer

and addressing them requires cooperation at all levels of governance. Even within a state, federal

or not, policy arrangements between the local (regional) and the national are becoming increasingly important in shaping domestic policymaking. ${ }^{3}$ Regional and international agreements like the EU and NAFTA are infringing daily on the sovereignty of states. Such terms as globalization or fragmegration have been bandied about to describe this interplay between the local, the national, the regional and the international. ${ }^{4}$ The use of such terminology is mostly descriptive however. They are not theories and do not help provide prescriptions for policymaking in the global system. The purpose of this article is to begin building a theory of multi-level governance and to study its applicability within the financial services sector of Canada. I do not elaborate a full-blown theory of multi-level governance. Instead, I am content to lay the groundwork for the construction of such a theory. The objective of a theory of multilevel governance is to bridge the gap between all levels of authority (public and private) involved in a particular policy area and to identify avenues for effective policymaking in such situations. This article will be divided into four parts. First, I look at the inadequacies of the treatment by some key theories of political science and international relations of the emergence of new forces of authority. Then, I draw the contours of a theory of multi-level governance. Third, I assess the evolution of multi-level governance in the banking sector in Canada. Last, I suggest further avenues of research in theorizing about multi-level governance. 


\section{The Inadequacies of Current Theories}

\section{Federalism}

In this section, I draw out the weaknesses of theories of federalism and regime theory, both of which represent established methods of addressing complex overlapping forms of political authority. I focus on federalism studies, recognizing the wide variety within this field, because of its evident link to the concept of multi-level governance. Federalism can be defined as:

a political system in which most or all of the structural elements of the state (executive, legislative, bureaucratic, judiciary, army, police, and machinery for levying taxation) are duplicated at two levels, with both sets of structures exercising effective control over the same territory and population. Furthermore, neither set of structures (or level of government) should be able to abolish the other's jurisdiction over this territory or population. As a corollary of this, relations between the two levels of government will tend to be characterized by bargaining, since neither level can fully impose its will on the other. ${ }^{5}$

Federalism studies tend to focus on the relationship between the central government and regional governments. In Canada, this has led to theories of cooperative, executive and more recently collaborative federalism. Executive federalism, as coined by Donald Smiley and used for over twenty years in Canadian politics, refers to "the relations between elected and appointed officials of the two orders of government in federal-provincial interactions and among the executives of the provinces in interprovincial relations. ${ }^{6}$ Others, like Cameron and Simeon, now argue that Canada is moving towards collaborative federalism. ${ }^{7}$ In such a system, the tensions that are said to exist in executive federalism are muted as both levels of governments work together towards common policy goals. These theories of intergovernmental relations continue to be used 
Roberge, Theory of Multi-Level Governance extensively, not only to describe the Canadian reality, but also that of other federal states.

Federalism studies have moved far beyond studying a single country using the comparative method to draw out conclusions about the political process across federal countries. Just as interesting is the use of federalism theories to describe the integration process of the European Union (EU). Michael Burgess is persuasive in describing the EU as a federation project. In his book Federalism and European Union: The Building of Europe 1950-2000, the author spends a great deal of time elaborating how the EU actually responds to the philosophies that underpin federalism. Also emerging in the field is an increase interest in the federations of the developing world. In that sense, federalism remains at the forefront of political inquiry.

Although many states have a federal structure, federalism studies have not been successful in addressing internationalization of public policy. First and foremost, a federation by definition is a single state. Studies of federalism are interested in the interaction between two levels of governments within the borders of a state. The problem is that while the state may well remain the principal agent of policymaking, policy issues now transcend national borders and require collaboration between multiple levels of authority, a reality that is not yet accurately described by federalist scholars. Federalism studies often ignore the role of very local governments and their key participation in many globalized policy areas, like the environment. Theories of federalism also have a hard time accounting for the increasing power of regional and international bodies of policymaking. While the EU may be considered federal in nature, federalism studies have traditionally not studied the interplay between three levels of governance as occurring in the Union with the increasing role of regions. While it may not be hard to adapt 
existing theories to this three-level reality, this effort has yet to be undertaken. How do we adapt

the theories of federalism when three levels of authority are present in policymaking, possibly including, also, the international arena? Lastly, by focussing on the state, theories of federalism are only now starting to pay attention to the role of private actors in governance. All of this is not to suggest that federalism studies cannot provide a solid foundation on which to study the internationalization of policy. Its strongest point remains its focus on the jurisdictional division of powers between central and regional governments. Delimiting policy jurisdictions is certainly one of the principal challenges of studying policymaking across levels of governance.

\section{Regime Theory}

Regime theory in international relations is almost thirty years old and a potent tool in the study of international relations. Its strength (some have argued its weakness) lies in the flexibility of the concept of regime. The classic definition of a regime is well-known: "International regimes are defined as principles, norms, rules and decision-making procedures around which actors'

expectations converge in a given issue-area". 8 A regime, then, can encompass anything from an international organization to a rather loose degree of cooperation between states. According to Hasenclever, Mayer and Rittberger, the field of regime theory is divided between realists, neoliberals and cognitivists. ${ }^{9}$ Realists argue regimes are the result of underlying power struggles within states. For them, the institutions created by regimes are weak and malleable to states' needs and interest. It is within this stream of study that we find scholars using the theory of hegemonic stability. For neo-liberals, regimes are the result of states collaborating with each 
other. The shared interest of participants in providing a public good that is unobtainable without

cooperation helps create strong international institutions. Cognitivists, for their part, are interested in the norms and principles that underlie a regime. They are interested in the constitutive norms of the regime and the evolution of those norms through the interaction of players over time. Institutions are strong and become participants of their own within regimes. Seen in this way, regime theory is not a unified theory and provides multiple views, sometimes even contradictory, of the international system. It has, however, been used to explain everincreasing cooperation in international relations in such fields as trade, finance, the environment, human rights, arms control, the fight against international crimes, and more. In other words, regime theory is used extensively to describe the interplay between key actors in the global system.

But is regime theory adequate to help us understand the process of globalization and that of the internationalization of public policy? Regime theory does have some strengths in these areas. For one, it is issue-oriented. At the core of the theory is a focus on governance arrangements in a particular policy issue. Also of note is that regimes do not have to be solely constituted by states. International organizations, multinational corporations, and NGOs can all be important players in an international regime. Lastly, regime theory is flexible in its approach and area of study so that it can describe many different types of international arrangements. That being said, regime theory is plagued by many of the woes that underpin international relations. For instance, domestic politics are often ignored in the study of regime theory, despite even the focus of cognitivists on the regime's norms and values. While the introduction of two-level 
games by Putnam have made international relations scholars aware of the link between the

national and the international, there is still a tendency to see international politics as distinct from processes of domestic politics. ${ }^{10}$ That clearly cannot continue at a time when many of the policy issues that confront our world cut across and transcend national borders. Regime scholars do not

study the vertical collaboration between the different levels of authority that is required to solve these policy issues. While providing a good base to understand international negotiations, regime theory does not provide any sense of the jurisdictional division of powers in any policy field. Lastly, regime theory, like most theories in international relations, has tended to ignore the role of sub-national and local actors in the international sphere.

Federalism studies and regime theory provide a solid foundation by which we can study the internationalization of public policy. However, neither of them provides a very complete picture of the new policy challenges in an era of increasing globalization. My objective, therefore, is to start putting forward a theory that builds on this theoretical knowledge but that can offer a more holistic approach to understanding the evolving global system. As such, I begin construction on a theory of multi-level governance.

\section{The Contours of a Theory of Multi-Level Governance}

\section{The Literature on Multi-Level Governance}

Up to this point in the literature, multi-level governance has mostly been used in studies relating to the EU. The EU represents the most elaborate form of regional integration seen to date. The 

EU arguably has strong supra-national institutions with legitimate powers of rule-making, while

states are said to retain their national sovereignty. Within the EU literature, the concept of multilevel governance has been used in a variety of ways. Andrew Jordan identifies its rise with the decline of (neo)-functionalism. He argues that Puchala is the father of multi-level governance theory with his emphasis in 1972 on 'concordance'. This is defined as: “... an international system wherein actors find it possible consistently to harmonise their interests, compromise their differences and reap mutual rewards from their interactions. ${ }^{11}$ Jordan adds that in such a system: “1) states are pre-eminent but not necessarily all-powerful; 2) actors operate at different levels (subnational, national, European and International); 3) levels of interaction between the various levels vary significantly across policy sectors". ${ }^{12}$ While this conceptualization of multi-level governance remains to this day one of the best in the literature, concordance as described above is very similar to regime theory's liberalism with all of its strengths and weaknesses.

That being said, multi-level governance has really gained popularity in the 1990s. Marks, Hooghe and Blank present multi-level governance as an integration theory countering intergovernmental approaches to EU studies. ${ }^{13}$ Focussing more on issues of democracy and legitimacy, Markus Jachtenfuchs also uses multi-level governance as a theory of integration. ${ }^{14}$ Others, like Scharpf, use the concept of multi-level governance to study the policymaking process at the EU level. ${ }^{15}$ Still others have looked at the response of national governments to EU Directives. ${ }^{16}$ The principal weakness of these studies is that they rarely provide a clear definition of multi-level governance. While the concept is certainly demonstrated as being valid 

(especially within the perspective of the EU), almost no effort is made to theorize per se about multi-level

governance. While this lack of theorizing may be characteristic of many concepts in political science, it is problematic if building a theory of multi-level governance is considered important in the context of the internationalization of public policy.

It is also interesting that the EU institutions themselves use the term multi-level governance. The Commission of the EU, in preparing its White Paper on European Governance, published in 2001, put together a Working Group on multi-level governance. ${ }^{17}$ This Working Group, in its report to the Commission, focused specifically on the relationship between the regions and the EU. The report is built around case studies without much elaboration on the concept of multi-level governance. Of course, such reports are intended to be practical and not theoretical in nature. The concept of multi-level governance has also been used by the OECD. In its report entitled Managing Across Levels of Governments, the OECD focuses on the relationship between central and local governments across member states from an administrative point of view. ${ }^{18}$ The interest of this report is twofold. First, it did not only study federations but also looked at arrangements between governments in what are traditionally unitary states. Second, the trend in OECD states toward decentralization is made clear demonstrating unequivocally the role of local authorities in key areas of policymaking. The missing element in this report, obviously, is a jurisdictional division that is inclusive of regional integration efforts and international organizations. 
As I stated before, the literature on multi-level governance has tended to study the EU. One of the challenges, then, for anyone wanting to build a theory of multi-level governance is to generalize the concept outside of Europe. In their discussions of different international policy environments, Coleman and Perl actually seek to disentangle multi-level governance from its EU roots. ${ }^{19}$ In this article, multi-level governance is distinguished from intergovernmental negotiations, private regimes, and loose couplings. About multi-level governance, they state: “... multi-level governance is an arrangement where there is significant institutional development at both national and supranational levels, and where politicians, bureaucrats, and civil society actors

engage in a multitude of cooperative working arrangements that cross levels". ${ }^{20}$ In an international environment where there is multi-level governance, the policy agenda is set by a mixture of transnational and national policy communities; the elaboration of policy is done through, usually, intergovernmental relations, though it could also be done through a community of experts in a policy field, or through national governments; the implementation of policy is normally done by national authorities with the support of the expert community, though technically nothing prevents the policy from being implemented by a supra-national level of governance. The authors' focus on 'significant institutional arrangements', however, greatly limits the number of cases that could be studied through a multi-governance lens. In fact, despite the attempt to do otherwise, only the EU really fits within Coleman and Perl's conception of multi-level governance. In other words, the required disentanglement process away from Europe has not really been achieved. 
Perhaps the most comprehensive survey of the literature on multi-level governance has been provided through another article by Hooghe and Marks. These authors now argue that there are two different types of multi-level governance arrangements:

The first conceives of dispersion of authority to a limited number of non-overlapping jurisdictions at a limited number of levels. Jurisdictions in this system of governance tend to bundle authority in quite large packages; they are usually non-overlapping; and they are relatively stable... A second distinctive vision of governance pictures a complex, fluid, patchwork of innumerable, overlapping jurisdictions. These jurisdictions are likely to have extremely fungible competencies, which can be spliced apart into functionally specific jurisdictions; they are often overlapping; and they tend to be lean and flexible - they come and go as demands for governance change. ${ }^{21}$

But which of these two models of multi-level governance is more efficient? This article aims to be more prescriptive and to allow for some generalizations to be made regarding multi-level governance arrangements.

\section{Defining Multi-Level Governance}

The first step in elaborating a theory of multi-level governance is to properly conceptualize and operationalize the expression under study. To do so requires breaking down the concept into its two main components; that is, its multi-level component and its governance component. The expression multi-level refers to a juxtaposition of authorities from the local, to the national, to the regional, to the international levels all having jurisdictional powers, though of varying degrees, in a policy field. In other words, multi-level refers to vertical institutional relationships between different levels of political authority towards the end of solving a policy 
Roberge, Theory of Multi-Level Governance problem. The only requirement for the existence of the multi-level component to exist is that

there be, at least, two distinct levels of political authority with some form of jurisdiction in a policy field. In that sense, it is true that a federation represents a form of multi-level governance arrangement. There are no theoretical limits to the number of levels that can exist in the management of a policy field as it is possible to go from the very local to the global. In that respect, governance arrangements can be established between local authorities and international ones without going through national authorities. Seen in this way, multi-level governance is territorially-based.

The second part of the concept is governance, which must first be distinguished from governments. While the term government tends to refer to the apparatus of the state and its elected representatives, governance is here understood as:

... the sum of the many ways individuals and institutions, public and private, manage their common affairs, ... a continuing process through which conflicting or diverse interests may be accommodated and cooperative action may be taken. It includes formal institutions and regimes empowered to enforce compliance, as well as informal arrangements that people and institutions either have agreed to or perceive to be in their interests. ${ }^{22}$

Three aspects of governance are important for our purpose. First, governance activities are not only carried out by the public sector, but also by private actors. In that respect, the study of private regimes has become an important part of the international political economy literature. Second, governance is not solely about formal arrangements, such as laws and policies on the public side, or codes, standards and contracts on the private side. Informal arrangements, as driven by norms and values, must also be taken into account when defining governance. Last, for governance arrangements to matter, they must lead to compliance. Any definition of multi- 
level

governance must take into consideration the three key components of governance. Hence, multilevel governance is also functions-based.

In the literature, I have been able to find two definitions of multi-level governance. For Michael Howlett, multi-level governance is:

... processes of policy-making in which central and other governments are mutually dependent, in which coordination between levels or orders of governments is necessary and in which policy is typically achieved through processes of negotiations and cooperation because there is no clear hierarchical order between levels. $^{23}$

The problem with this definition is that it emphasizes a process between governments to the exclusion of the role of the private sector in governance arrangements. For their part, Peters and Pierre define multi-level governance as follows: "negotiated, non-hierarchical exchanges between institutions at the transnational, national, regional and local levels". ${ }^{24}$ They then add that multi-level governance also refers to a vertical 'layering' of governance processes at these different levels. ${ }^{25}$ The weakness of this definition is its reference to "non-hierarchical exchanges'. How are multi-level governance structures non-hierarchical when they are vertical by nature? I propose my own definition of the concept. Multi-level governance refers to two or more levels of authority arranged vertically through formal or informal agreements, from public or private sources or both, established in a policy field so as to regulate and normalize activity in that field. This definition captures both aspects of the expression, that is, its multi-level component and its governance aspect, as well as establishes a dimension along which its strength can be measured for theoretical purposes. The following table helps us conceptualize multi-level 

governance even further. Of interest in studying the table is that it encompasses Hooghe and

Marks two models of multi-level governance as described earlier. Multi-level governance in this way becomes flexible, a concept that can be taken out of the EU setting, and that allows analysis of a wide variety of governance arrangements.

\begin{tabular}{|c|c|c|c|}
\hline \multicolumn{4}{|c|}{ Multi-Level Governance } \\
\hline & Levels of Governance & $\begin{array}{l}\text { Division of } \\
\text { Policymaking } \\
\text { Powers }\end{array}$ & Role of the Private Sector \\
\hline Weak & - 2 Levels of Authority & $\begin{array}{l}\text { - Clear (No } \\
\text { Duplication or } \\
\text { Overlap) }\end{array}$ & $\begin{array}{l}\text { - Point of Entry Limited to } \\
\text { One Level of Authority } \\
\text { - Limited Power of } \\
\text { Governance }\end{array}$ \\
\hline Medium & $\begin{array}{l}\text { - More than } 2 \text { Levels of } \\
\text { Authority (Possible } \\
\text { Participation of Either } \\
\text { Regional or International } \\
\text { Levels of Governance) }\end{array}$ & $\begin{array}{l}\text { - Clouded (Possible } \\
\text { Duplication and } \\
\text { Overlap) }\end{array}$ & $\begin{array}{l}\text { - Point of Entry Across } \\
\text { Levels of Authority } \\
\text { - Increased Power of } \\
\text { Governance }\end{array}$ \\
\hline High & $\begin{array}{l}\text { - More than } 2 \text { Levels of } \\
\text { Authority (Definite } \\
\text { Participation of Either of } \\
\text { Regional or International } \\
\text { Levels of Governance) }\end{array}$ & $\begin{array}{l}\text { - Clear (Possible } \\
\text { Duplication and } \\
\text { Overlap) }\end{array}$ & $\begin{array}{l}\text { - Point of Entry Across } \\
\text { Levels of Authority } \\
\text { - Definite Power of } \\
\text { Governance }\end{array}$ \\
\hline
\end{tabular}

\section{Multi-level Governance and the Canadian Banking Sector}

Canada has moved from a weak system of multi-level governance in banking (1867-1987) to a medium system today with expectations from the industry to now move towards a strong system of multi-level governance. In the British North American Act, banking is clearly a federal responsibility. As such, the federal government regulates what are termed chartered banks. But 
Roberge, Theory of Multi-Level Governance

the provinces have also claimed jurisdiction in traditional areas of the banking industry under the

'Property and Civil Rights' clause of section 92 of the Canadian constitution. Trust companies are of provincial responsibility due to the fact that these firms are doing 'estates' business and operating 'trusts' which are both understood to be aspects of private property. Generally speaking, the federal government saw credit unions and cooperatives as being a matter of local concern, and thus, it also left their regulation to the provinces. In this weak system of multi-level governance, the federal government and the provinces established a relatively separated delineation of jurisdictions. Within its jurisdiction, each level of government had clear legislative power. While the banking industry played a part in governing itself during this period (for instance, the Canadian Bankers Association was in charge of the payment system until 1980), policymaking is bureaucratic and the preserve of governments. Also of importance for this period is that there is no real international regime for banking. That is the case even though the Bank for International Settlements has existed since the days of the Great Depression ${ }^{\text {iii }}$. For this period of a hundred and twenty years, Canada had a weak system of multi-level governance with only two levels of government involved with little cooperation needed between the two, a technical role for the private sector, and little international involvement.

While this jurisdictional divide still obviously exists today, the elimination of the so-

\footnotetext{
iii The BIS groups central bankers, originally from G10 countries, but now also from a host of other states, in pursuit of monetary and financial stability. The BIS is the host of the Basle Committee on Banking Supervision. Together, they formulate broad regulatory guidelines and standards to be implemented by states in the regulation of their banking system. Note that this is not a traditional public international organization in that central bankers may be highly independent of national governments.
} 
has clouded the boundaries of this traditional governance arrangement. In 1987, banks were finally allowed to own securities firms, which were formerly under provincial jurisdiction. In 1992, banks were permitted to buy provincially regulated trust companies. Also at this time, the banking sector is allowed, through subsidiaries, to participate in the insurance market. A key change in this period is the slow democratization of the banking policy process. Bureaucrats do not solely decide banking policy any longer, private actors are now much more consulted in the orientation and content of policy.

Just as important, during the last twenty years there have been many attempts to (re)regulate international finance. Of note in banking is the Basle Capital Adequacy Accord of 1988 which lays out required capital ratios for banks ${ }^{\mathrm{v}}$. This Accord, now under revision, is seen as the pre-eminent example of the capacity of states to negotiate a successful agreement in the field of banking and finance. In fact, the international regime for banking has grown substantially since the early 1970s. The G7 monitors financial activity on a yearly basis. Under the World Trade Organization (WTO), the General Agreement on Trade in Services (GATS) has been signed requesting that states liberalize their banking and financial sectors. Regionally, chapters 11,14 and 20 of the North American Free Trade Agreement (NAFTA) all refer to the requirements for member states to liberalize their financial services sector. The WTO and the NAFTA are of

\footnotetext{
${ }^{\text {iv } U p ~ u n t i l ~ t h i s ~ p e r i o d, ~ t h e ~ C a n a d i a n ~ f i n a n c i a l ~ s e r v i c e s ~ s e c t o r ~ w a s ~ c l e a r l y ~ s e g r e g a t e d ~ b e t w e e n ~ b a n k i n g, ~ i n s u r a n c e, ~}$ trusts and the securities sector.

'The Accord was negotiated within the confines of the BIS' Basle Committee on Banking Supervision. It defines capital ratios requirements which refer to the amount of capital reserves that banks must have at all times to ensure 
foreign banks allowing them now to operate branches, and not only subsidiaries, in Canada. There is, however, a lack of coordination between all of these policy initiatives. In regards to banking activities, there are no cooperative working arrangements between the federal government, provinces and international players. In other words, banks are under federal law and regulation for their traditional activities; they are under provincial regulation when offering their clients investment services; they must now compete with foreign firms as a result of the WTO and NAFTA; and, their capital ratio has been determined by an international agreement. The cost of such an uncoordinated system is obviously a burden for the banking industry. This is a medium system of multi-level governance in that we are now dealing with four levels of authority, although un-coordinated, which include regional and international attempts at governance and regulations and increase participation in governance arrangements by the private sector at all levels of authority.

There are inklings that Canada may be moving towards a strong system of multi-level governance in banking. Coleman notes that one of the actual effects of the breaking down of the four pillars is that it is slowly leading to a centralization of power to the federal authority. ${ }^{26}$ There are few independent trusts in Canada with the majority of trusts business being done by the major banks. Credit unions and cooperatives are part of their provincial centrals which themselves help form the Credit Union Central of Canada, a federally regulated body. Bill C8, the latest legislative revision of Canada's financial services sector, also has measures to facilitate 
the provincial cross-border activities of co-operatives. There have also been discussions over the

last five years about the creation of a national co-operative bank. Canada now has a centralized ombudsman service that covers the entire financial services sector, whether the complaint is on provincially-regulated or federally-regulated firms. Lastly, the rationalization of Canada's stock exchanges at the end of the $1990 \mathrm{~s}^{\mathrm{vi}}$ and attempts to harmonize provincial securities regulations also demonstrate a centralization movement in the investment field. In such a system, then, the central authorities have clear responsibility over most of Canada's financial sector, letting the provinces regulate small parts of the industry as required for regional economic development. At the NAFTA level, Canadian banks would like Canada to move towards regulatory integration with the United States. After all, with provisions in US law prohibiting inter-state banking and operations across pillars of the finance industry being lifted in the 1990s, Canadian banks are increasingly seeking to make a dent in the nationalising American marketplace. Internationally, the revised Capital Accord being negotiated and on the verge of being agreed to should strengthened the international regime in banking. It is, however, much too early to describe Canada as a strong multi-level governance system. The centralization process that I am referring to is only now starting to take shape and there are no attempts at regulatory harmonization or integration among NAFTA partners. All of this being said, it is very clear that Canada's

\footnotetext{
${ }^{\mathrm{vi}}$ Through this rationalization is that the Toronto Stock Exchange becomes the principle exchange for primary trading (the issuance of new securities), and secondary trading (the exchange of existing securities) in Canada with the Montréal Stock Exchange focusing on futures trading, and the Vancouver, Calgary Stock Exchanges becoming the Canadian Ventures Exchange.
} 
Roberge, Theory of Multi-Level Governance governance arrangements in the field of banking have vastly changed over the course of the last twenty years and are still going through a period of flux.

\section{Conclusion}

If globalization represents a paradigm shift for political science and if the new environment is characterized by the internationalization of public policy, it is imperative that we revise old theories in the discipline taking into consideration that the state is not to be the focal point of all analysis. In that sense, this article has served to build the foundation for a theory of multi-level governance. I have also shown the usefulness of the multi-level governance concept in describing the evolution of governance arrangements in banking in Canada.

In the European context, Jordan makes five major criticisms of multi-level governance. ${ }^{27}$ First, he states that such theorizing is not new. Second, he argues that multi-level governance is at best a descriptive tool but that it is not a causal model of analysis. Jordan also argues that multi-level governance analysis overstates the power of sub-national actors in the EU, and does not theorize adequately the relationship between these actors and regional and international forums of governance. Fourth, he argues that multi-level governance generally ignores the relationship between private and public authorities. Last, Jordan argues that multi-level governance traditionally ignores the international sphere of analysis. Through my own conceptualization and operationalization of multi-level governance, I answer many of Jordan's criticisms. This is partly done by not identifying multi-level governance as being solely a reality of the EU. In that sense, the powers of sub-national actors are not overstated, as they will vary from policy sectors to policy sectors. Our proposed theory of multi-level governance is inclusive 
Roberge, Theory of Multi-Level Governance of private regimes. I also include the international level as a distinct level of governance. Where Jordan is entirely right is that multi-level governance has been used extensively to describe

various political systems but that it does not provide causal explanations. My conceptualization of weak, medium and strong system of multi-level governance should move those interested in the field in the proper direction. That is so because such a conceptualization allows us to generalize across systems of multi-level governance.

For those interested in building a theory of multi-level governance, it is time to start asking more pointed questions about multi-level governance arrangements and their impact on policymaking. What I have put forth here allows us to make propositions about systems of multi-level governance. For instance, what explains the shift from a weak to a medium or a strong system of multi-level governance? A possible hypothesis here, partly supported by the Canadian experience in banking, is that such shifts have occurred because of a redistribution of power between governing authorities. Such redistribution can imply new arrangements between the public and the private sector. How does the existence of multi-level governance systems impact policymaking at any of the levels of authority? It could be hypothesized that the impact of such systems on policymaking is that the policy process, like in a (neo)-functionalist system, is now more technocratic and less democratic as subject matters become more and more complicated and lines of accountability are blurred. What types of relationships exist between the different levels of authority? It could be argued, out of collaborative federalism, that policy is more easily obtainable when common policy goals exist at all levels of governance. Does multi-level governance provide viable and efficient solutions to policy issues? That question is 

important in that it is the purpose of multi-level governance systems, but only through studying governance arrangements across regions and sectors would we be able to find out if that is indeed

the case. These questions and the proposed hypotheses demonstrate how building a theory of multi-level governance can help us better understand the new realities linked to the internationalization of public policy.

Multi-level governance may not be new; however, it is particularly well-suited to analyse a changing world order. As such, I have provided the framework by which a full-blown theory of multi-level governance can be elaborated. A lot of work is on our plate if we are to establish such a theory. The payoff of this work, however, is clear - it is a theory that is fluid enough to account for changes and variations in global society, sufficiently structured to help make propositions explaining real world events, and 'beautiful' so as to be easily understandable. These, after all, are the goals of all good social theories! 


\footnotetext{
$\underline{\text { Notes }}$

${ }^{1}$ James N. Rosenau, Turbulence in World Politics: A Theory of Change and Continuity

(Princeton: Princeton University Press, 1990).

${ }^{2}$ Robert O. Keohane and Helen V. Milner, Internationalization and Domestic Politics

(Cambridge: Cambridge University Press, 1996).

${ }^{3}$ Organization for Economic Cooperation and Development. Managing Across Levels of Government: Overview 1997.

${ }^{4}$ James N. Rosenau, "States, Sovereignty and Diplomacy in the Information Age" http://www.usip.org 1998.

${ }^{5}$ Garth Stevenson, Unfulfilled Union: Canadian Federalism and National Unity, Third Edition, (Toronto: Gage Educational Publishers, 1989) 8.

${ }^{6}$ Ronald Watts, "Executive Federalism: The Comparative Perspective," Federalism and Political Community: Essays in Honour of Donald Smiley, eds. David P. Shugarman and Reg Whitaker (Peterborough: Broadview Press, 1989) 440.

${ }^{7}$ David Cameron and Richard Simeon, "Intergovernmental Relations in Canada: The Emergence of Collaborative Federalism," Publius 32, 2 (Spring 2002).

${ }^{8}$ Stephen D. Krasner (ed.) International Regimes. (Ithaca and London: Cornell University Press, 1983) 1.

${ }^{9}$ Andreas Hasenclever, Peter Mayer and Volker Rittberger, Theories of International Regimes

(Cambridge/New York: Cambridge University Press, 1997).

${ }^{10}$ Robert Putnam, "Diplomacy and Domestic Politics: The Logic of Two-Level Games." International Organizations 42 (Summer 1988) 427-460.

${ }^{11}$ Andrew Jordan, "The European Union: An Evolving System of Multi-Level Governance ... or Government," Policy and Politics 29, 2 (2001) 198.

12 ibid.

13 Gary Marks, Liesbet Hooghe and Kermit Blank, "European Integration from the 1980s: StateCentric v. Multi-level Governance". Journal of Common Market Studies 34, 3 (September 1996).

${ }^{14}$ Markus Jachtenfuchs, “The Governance Approach to European Integration”. Journal of Common Market Studies (June 2001) 245-263.

${ }^{15}$ Fritz W. Scharpf, "Community and Autonomy: Multi-Level Policy-Making in the European Union". Journal of European Public Policy 1, 2 (Autumn 1994) 219-242.

${ }^{16}$ Fritz W. Scharpf, "Introduction: The Problem-Solving Capacity of Multi-Level Governance". Journal of European Public Policy 4, 4 (December 1997) 520-538.

${ }^{17}$ Commission of the European Union. Multi-Level Governance: Linking and Networking the Various Regional and Local Levels. Report by Working Group. 2001.

${ }^{18}$ Organization for Economic Cooperation and Development. Managing Across Levels of Government: Overview. 1997.

${ }^{19}$ William D. Coleman and Anthony Perl, "Internationalized Policy Environment and Policy Network Analysis”. Political Studies XLVII, 4 (1999) 691-709.
} 
20 ibid., 701.

${ }^{21}$ Liesbet Hooghe and Gary Marks, “Types of Multi-Level Governance”. European Integration On-Line Paper 5, 11 (2001).

${ }^{22}$ Barry R.J. Jones, The World Turned Upside Down: Globalization and the Future of the State (Manchester/New York: Manchester University Press, 2000) 2.

${ }^{23}$ Michael Howlett, "Federalism and Public Policy." Canadian Politics, Third Edition, eds. James Bickerton and Alain G. Gagnon (Peterborough: Broadview Press, 1999) 525.

${ }^{24}$ Guy P. Peters and Jon Pierre, "Development in Intergovernmental Relations: Towards MultiLevel Governance". Policy and Politics 29, 2 (2001) 131.

${ }^{25}$ ibid., 132.

${ }^{26}$ William D. Coleman, Federalism and Financial Services. Forthcoming.

${ }^{27}$ Andrew Jordan, "The European Union: An Evolving System of Multi-Level Governance ... or Government," Policy and Politics 29, 2 (2001). 